\title{
Six new species of Microlicia (Melastomataceae) from Bahia, Brazil
}

\author{
Rosana Romero ${ }^{1}$ \& Elizabeth M. Woodgyer ${ }^{2}$
}

Summary. Microlicia abairana, M. aureoglandulosa, M. crispa, M. curticalycina, M. ganevii and M. restingae are described from Bahia state, Brazil. Comprehensive descriptions of the species are provided, including detailed illustrations, and statements of geographical distribution, habitat and IUCN conservation status.

Resumo. Microlicia abairana, M. aureoglandulosa, M. crispa, M. curticalycina, M. ganevii e M. restingae são descritas para o estado da Bahia, Brasil. São fornecidas descrições abrangentes das espécies, incluindo ilustrações detalhadas, e dados de distribuição geográfica, habitat e estado de conservação da IUCN.

Key Words. campo rupestre, Catolés, endemic, IUCN categories, Microlicieae, restinga.

\section{Introduction}

The genus Microlicia was originally established by Don (1823) with five species. By the end of the 19th century, 99 species of Microlicia were recognised by different authors (De Candolle 1828; Chamisso 1834; Naudin 1845, 1849; Cogniaux 1883, 1891), of which only 10 occurred in Bahia (Cogniaux 1883, 1891). In the first half of the 20th century Ule (1908), Hoehne (1922), Brade (1962) and Markgraf (1927) described nine new Bahian species. Wurdack (1981, 1982, 1983, 1995) studied Melastomataceae collections made by Raymond M. Harley in Bahia throughout the 1970s and 1980s and, based on the duplicates sent to the US herbarium, described 32 new species in different genera, of which at least 15 represented new species of Microlicia. Seven species of Lavoisiera were transferred to Microlicia (Almeda \& Martins 2001), three of which were described by Wurdack (1974, 1988, 1995). Over the past 10 years, nine new Bahian species have been described by Woodgyer \& Zappi (2005, 2009), Almeda \& Martins (2012) and Pataro et al. (2013).

Currently Microlicia has approximately 130 species, of which 126 are endemic to Brazil (Romero \& Woodgyer 2016). Most of the species occur in campos rupestres (Romero \& Martins 2002) and are most diverse in Minas Gerais (69 spp.) and Bahia (48 spp.) with high endemism in both states (Romero \& Woodgyer 2016).

Microlicia have close affinities with Lavoisiera DC. (Almeda \& Martins 2001). Species of Microlicia typically have 5-merous flowers, pedicellate to subsessile, solitary, with a typically 3-locular, superior ovary, and capsular fruits with dehiscence longitudinally from the apex to the base (Cogniaux 1883, 1891). Lavoisiera is distinct in having 5-8-merous flowers, rarely 9merous, a 4 - to 8-locular ovary that is always partly inferior, and capsular fruit with longitudinal dehiscence from the base to the apex (Almeda \& Martins 2001). In Microlicia, the stamens are often dimorphic (Cogniaux 1883, 1891; Woodgyer 2005) with the larger stamens arranged in the antesepalous whorl, while the smaller stamens are in the antepetalous whorl. Some species from Bahia have isomorphic or subisomorphic stamens (Wurdack 1983, 1995; Woodgyer 2005).

The 48 species of Bahian Microlicia (Romero \& Woodgyer 2016), are augmented by six further species described herewith, but this number is sure to increase as, from our studies of herbarium material, it is possible to see that there are more species still to be described.

Within floristic surveys of Melastomataceae in Bahia, Microlicia is the least well-known genus, hence a number of partial determinations (Woodgyer \& Nic Lughadha 1995; Zappi et al. 2003; Santos \& Silva 2005; Aguiar 2012). This highlights the need to carefully study the material available and describe the new taxa (Woodgyer \& Zappi 2005, 2009; Pataro et al. 2013).

The difficulties of recognising and circumscribing species in this complex genus have led to the extensive study of Microlicia specimens deposited at Kew within the scope of the REFLORA Programme. Kew's collection houses $91 \%$ of the currently recognised species of Microlicia and is rich in type specimens. Besides the resolution of taxonomic issues (Romero 2013a, b; Romero \& Woodgyer 2014), a further 13 new species were recognised amongst partly determined collec-

\footnotetext{
Accepted for publication 17 April 2018. Published online 3 May 2018

1 Instituto de Biologia, Universidade Federal de Uberlândia, Rua Ceará s.n., Bloco 2D, Uberlândia, Minas Gerais, 38400-902, Brazil. e-mail: rosana.romero@ufu.br

2 Herbarium, Royal Botanic Gardens, Kew, Richmond, Surrey, TW9 3AE, UK. e-mail: e.woodgyer@kew.org
} 
tions and are currently under study (Romero \& Woodgyer in prep.).

\section{Materials and Methods}

This study was based on the literature and on the analysis of specimens of Microlicia deposited mainly in $\mathrm{K}$ and HUFU herbaria, with duplicates in the following herbaria: CAS, CEPEC, HUEFS, IPA, MBM, MO, NY, RB, SP, SPF, UEC and US (Thiers [continuously updated]). Measurements of the vegetative parts and fruits were made on dry herbarium specimens. The flowers were rehydrated before taking measurements under a Leica MZ6 Stereo Zoom Microscope with an eyepiece graticule.

In the species descriptions that follow, we often refer to spherical, golden glands. These appear sessile when examined under a hand lens or light microscope and have been described by us as sessile, spherical, golden glands in past papers dealing with the genus. However, recent studies have revealed that these glands have a minute stalk or peduncle (Romero et al. 2015a; Romero et al. 2015b). We have therefore avoided describing the glands as "sessile" despite their appearance.

Based on georeferenced data from cited collections, the area of occupancy and extent of occurrence were calculated using GeoCAT (Bachman et al. 2011).

\section{Taxonomic Treatment}

Microlicia abairana $R$. Romero $\mathcal{E}$ Woodgyer, sp. nov. Type: Brazil, Bahia: Mun. Abaíra (Município), Campo de Ouro Fino (alto), $13^{\circ} 15^{\prime} \mathrm{S}, 41^{\circ} 54^{\prime} \mathrm{W}, 1700-1800 \mathrm{~m}$, 17 Jan. 1992, Hind E Queiroz in H50065 (holotype HUEFS!; isotypes CEPEC, HUFU!, K!, NY, SPF!).

http://www.ipni.org/urn:lsid:ipni.org:names:77177996-1

Erect, much-branched shrub $0.4-0.8 \mathrm{~m}$ tall. Young branches quadrangular, 4-winged, densely covered in spherical, golden glands, older branches becoming terete, glabrous and leafless with age. Leaves ascending to slightly horizontal, concolorous, wrinkled; sessile or petiole $0.3-0.4 \mathrm{~mm}$ long; blade lanceolate, $3-4 \times 0.6-0.8$ $\mathrm{mm}$, apex acute, base attenuate, margin entire or barely undulating, midrib evident at base of abaxial surface, both surfaces covered with spherical, golden glands, slightly glutinous. Flowers 5-merous, solitary, terminal or lateral, zygomorphic due to position of stamens and style; pedicel 0.3 - $0.6 \mathrm{~mm}$ long. Hypanthium oblong to oblongcampanulate, $3.5-4 \times 2-2.5 \mathrm{~mm}$, smooth, cream, with spherical, golden glands; sepals ascending, oblong, cylindrical, $1.2-1.6 \times 0.3-0.4 \mathrm{~mm}$, with spherical, golden glands, apex obtuse. Petals oblong, $5.7-6.3 \times 2.6-3.2 \mathrm{~mm}$, yellow, apex acute, margin entire. Stamens 10, dimorphic, yellow, anthers polysporangiate, pore ventral; large (antesepalous) stamens 5, filaments $3.5-4 \mathrm{~mm}$ long, thecae oval to oval-oblong, $1.5-2.5 \mathrm{~mm}$ long (including beak), beak $0.4-0.5 \mathrm{~mm}$ long, connective prolonged $3.5-4 \mathrm{~mm}$, ventral appendage $1.4-1.6 \mathrm{~mm}$ long, expanded and slightly acute; small (antepetalous) stamens 5, filaments $2.7-3.2 \mathrm{~mm}$ long, thecae oval-oblong, $1.8-2 \mathrm{~mm}$ long (including beak), beak $0.3-0.5 \mathrm{~mm}$ long, connective prolonged $1-1.3 \mathrm{~mm}$, ventral appendage $0.5-$ $0.6 \mathrm{~mm}$ long, obtuse. Ovary ovoid, $1.5-1.7 \times$ c. 1.3 $\mathrm{mm}$, superior, 3-locular, glabrous; style $4-5 \mathrm{~mm}$ long, stigma punctiform. Capsule $1.8-2.4 \times 1.7-$ $2.2 \mathrm{~mm}$, brown, globose, dehiscing into 3 valves from the apex, hypanthium covering entire capsule, peeling off as fruit matures. Seeds $0.3-0.4 \times 0.2-$ $0.3 \mathrm{~mm}$, numerous, slightly curved to one side, brownish, testa areolate and foveolate. Fig. 1.

RECOGNITION. Related to Microlicia monticola Wurdack, but differs in having slightly wrinkled leaves (vs smooth in $M$. monticola), acute apices, not aristate (vs attenuate apices with seta $0.2 \mathrm{~mm}$ long in M. monticola) and branches covered by spherical glands (vs pale trichomes in M. monticola).

DISTRIBUTION. Microlicia abairana occurs in the Catolés mountain area in the Mun. Abaíra, Bahia, where it seems to be endemic. Map 1.

SPECIMENS EXAMINED. BRAZIL. Bahia: Mun. Abaíra (Município), Campo de Ouro Fino (alto), $13^{\circ} 15^{\prime} \mathrm{S}$, $41^{\circ} 54^{\prime} \mathrm{W}, 1700-1800 \mathrm{~m}, 17 \mathrm{Jan} .1992$, Hind Eं Queiroz in H50065 (holotype HUEFS!; isotypes CEPEC, HUFU!, K!, NY, SPF!); Mun. Abaíra: Campo de Ouro Fino (baixo), $13^{\circ} 15^{\prime} \mathrm{S}, 41^{\circ} 54^{\prime} \mathrm{W}, 1600$ - $1700 \mathrm{~m}, 25$ Jan. 1992, Stannard, Pirani $\mathcal{E}^{\circ}$ Nic Lughadha in H50807 (K!, NY, SPF!).

HABITAT. Campo rupestre, in sandy soil between 1600 $1800 \mathrm{~m}$.

CONSERVATION STATUS. In 1999 the Conservation Area Serra do Barbado was created by the state government of Bahia comprising part of six municipalities, including Abaíra, where Microlicia abairana was collected. Although occurring in a Conservation Area, M. abairana should be considered Critically Endangered (CR) B2ab(iii) due to the restricted extent of occurrence and area of occupancy $\left(\mathrm{AOO}=4 \mathrm{~km}^{2}\right)$, according to the IUCN categories and criteria (IUCN 2001, 2016).

ETYMOLOGY. The specific epithet refers to the restricted occurrence of the new species, in Mun. Abaíra in the Chapada Diamantina, Bahia.

NOTES. Microlicia abairana resembles M. monticola, which is endemic to Rio de Contas (Wurdack 1983; Woodgyer \& Nic Lughadha 1995; Santos \& Silva 2005). Both have yellow petals, dimorphic stamens, polysporangiate anthers and small leaves (3 - $6 \times 0.5-2 \mathrm{~mm}$ in M. monticola). However, M. monticola differs in having branches with pale 


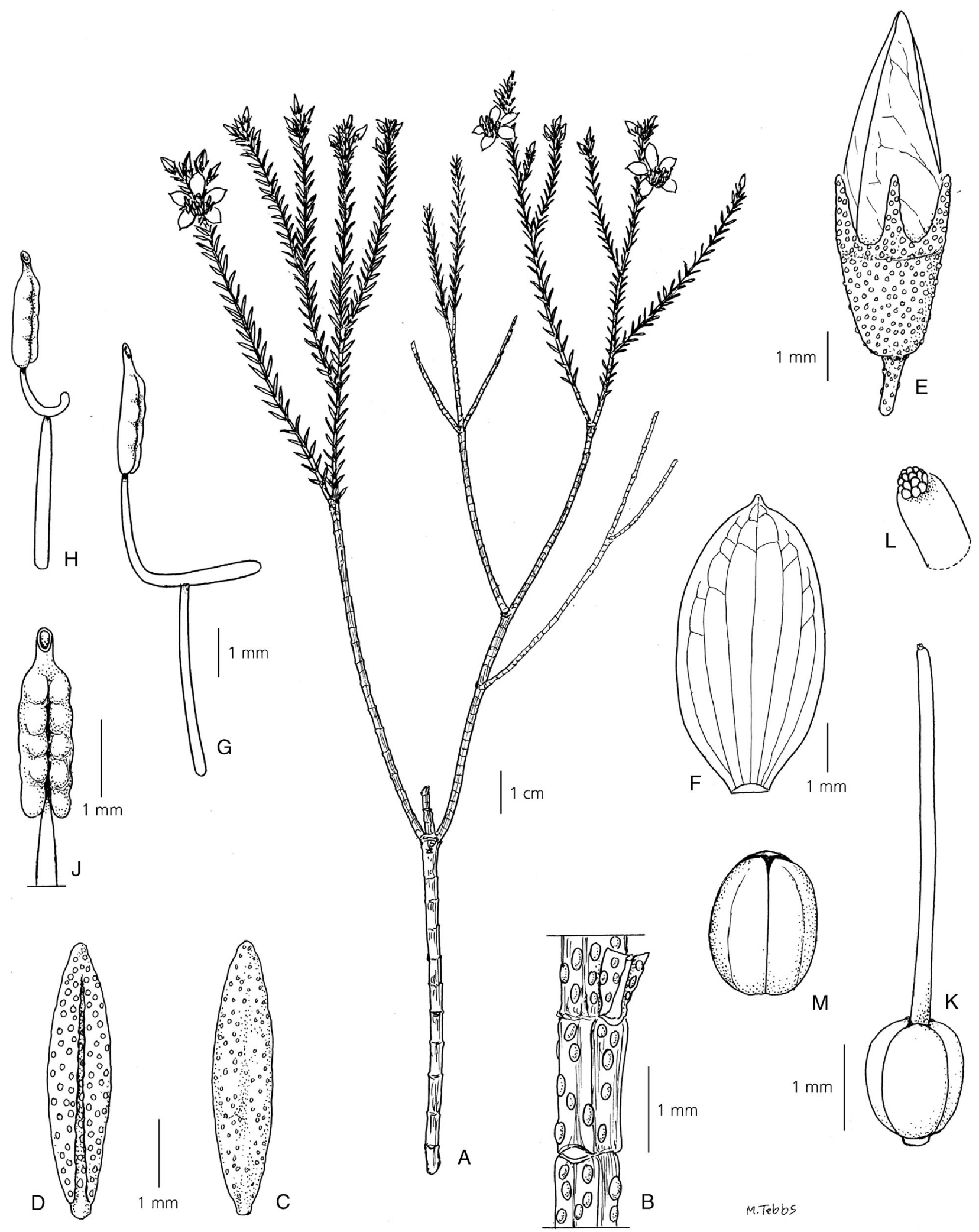

Fig. 1. Microlicia abairana. A habit; B stem detail (showing indumentum of spherical glands); C leaf adaxial surface; D leaf abaxial surface; E flower bud; F petal; G large (antesepalous) stamen; $\mathrm{H}$ small (antepetalous) stamen; J detail of polysporangiate anther; K gynoecium; L detail of stigma; M mature capsule. A, C - M from Hind \& Queiroz in H50065, B from Stannard et al. in H50807. DRAWN BY MARGARET TEBBS. 


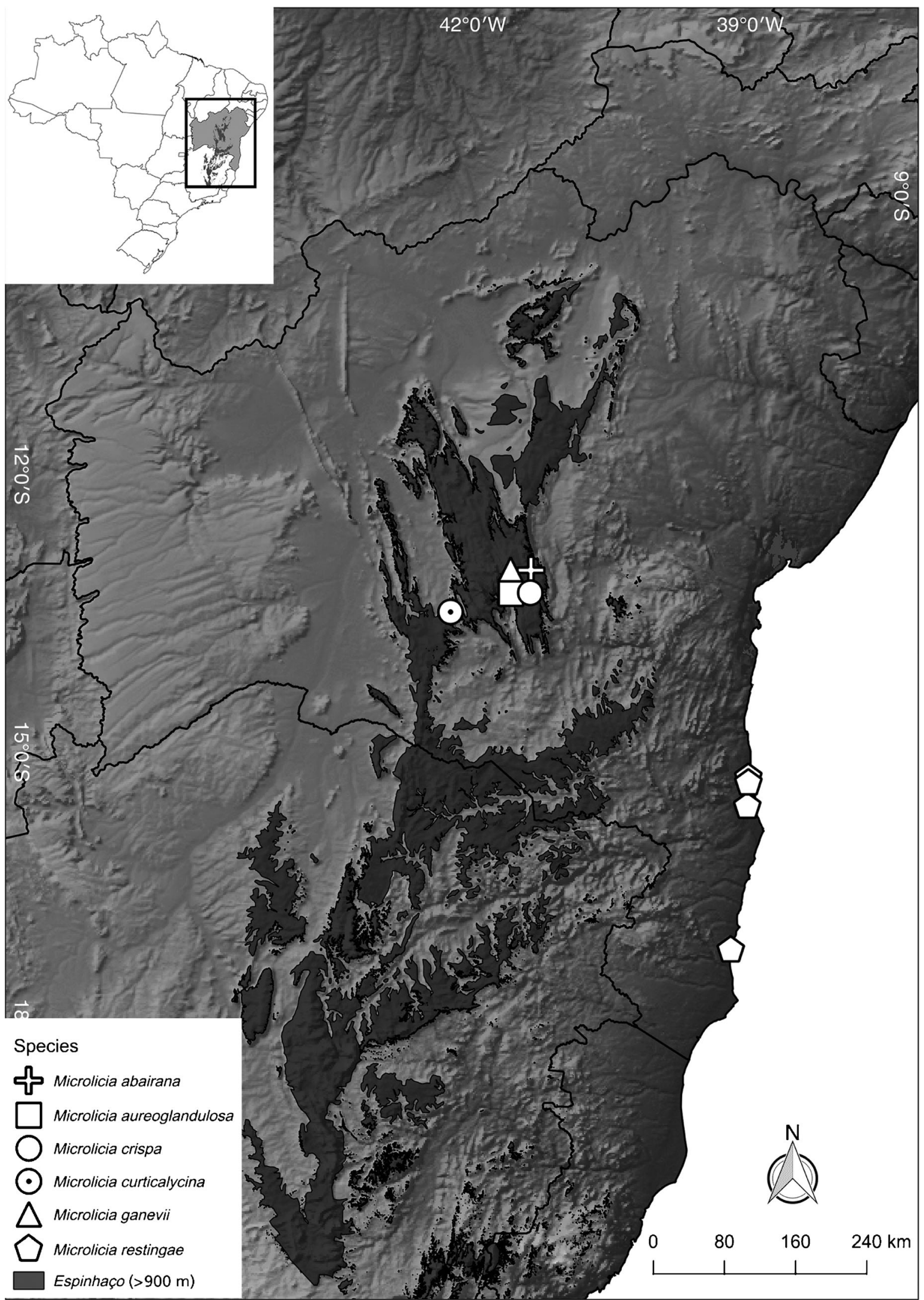

Map 1. Distribution of Microlicia abairana, M. aureoglandulosa, M. crispa, M. curticalycina, M. ganevii and M. restingae in Bahia, Brazil. 
trichomes, smooth leaves and attenuate apices with a seta $0.2 \mathrm{~mm}$ long. In $M$. abairana the branches are covered by glands only, both surfaces of the leaf blade have sunken glands making the leaves slightly wrinkled and the apices are acute and not aristate.

Microlicia abairana bears some resemblance to M. parvula (Markgr.) Koschn. \& A. B. Martins, which also occurs in Abaíra. Both have branches, leaves, hypanthia and sepals covered in glands, small leaves, yellow petals and stamens and polysporangiate anthers. Microlicia parvula is a xylopodiferous subshrub c. $50 \mathrm{~cm}$ tall, the leaves are wider $1-1.5 \mathrm{~mm}$, with rounded or cuneate bases, the sepals are triangular and c. $1 \mathrm{~mm}$ long and the stamens are isomorphic or subisomorphic.

Like Microlicia curticalycina R. Romero \& Woodgyer, M. abairana also has an indumentum of spherical, golden glands covering the whole plant, small leaves and yellow flowers. M. curticalycina differs, however, in having isomorphic stamens, oblong hypanthia, short triangular sepals $0.4-0.9 \times 0.7-0.9 \mathrm{~mm}$, anthers with a short beak $0.1-0.2 \mathrm{~mm}$ long and short connective $0.7-0.8 \mathrm{~mm}$ long.

If using the multi-access key to the species of Microlicia from Bahia (Woodgyer 2005), the formula for M. abairana is: CDGJNQUVae.

In the checklist of the vascular plants of Catolés, this collection is cited by Zappi et al. (2003) as Microlicia sp. 15.

Microlicia aureoglandulosa Woodgyer $\mathcal{E} R$. Romero sp. nov. Type: Brazil, Bahia, Mun. Abaíra, Serra do Rei, 1700 - $1900 \mathrm{~m}, 13^{\circ} 18^{\prime} \mathrm{S}, 41^{\circ} 56^{\prime} \mathrm{W}, 3$ Feb. 1994, fl. fr., Ganev 2929 (holotype HUEFS!; isotypes K!, NY, US).

http://www.ipni.org/urn:lsid:ipni.org:names:77178066-1

Much branched shrub or subshrub 60 - $80 \mathrm{~cm}$ tall. Young stems quadrangular, greenish-brown to yellowish-brown (dry state), slightly winged, internodes $1 \mathrm{~mm}$ long, dense indumentum of spherical, golden glands. Older branches leafless, leaf scars conspicuous giving a stepped appearance, bark greyish-brown flaking away in small pieces to reveal pinkish stem beneath. Leaves horizontal to inclined to ascending, mid-green, sometimes with adaxial surface brownishgreen (dry state); sessile or subsessile with petiole $0.2-$ $0.4 \mathrm{~mm}$ long; blade narrowly elliptic, $3-4.5 \times 0.6-0.9$ $\mathrm{mm}$, apex narrowly acute with thickened tip, margin entire, base obtuse to truncate; veins not discernible; glabrous, both surfaces densely impressed with spherical, golden glands. Flowers 5-merous, solitary or in clusters at tips of branches; sessile to subsessile. Hypanthium campanulate, $2.6-2.7 \times 2-2.6 \mathrm{~mm}$, yellow-brown (dry state), with dense, spherical, golden glands; sepals narrowly triangular, $1.8-2 \times 0.8-1$ $\mathrm{mm}$, yellow, indumentum as hypanthium, dense on outer surface, scattered on inner surface, apex narrowly acuminate with minute seta c. $0.1 \mathrm{~mm}$ long, margin entire. Petals asymmetrically obovate, $3.7-5 \times$ $2.7-4.2 \mathrm{~mm}$, yellow, apex apiculate, glabrous or with a few scattered spherical glands. Stamens 10, isomorphic, all parts yellow, filaments $1.5-1.9 \mathrm{~mm}$ long, thecae $1.6-1.9$ (including beak) $\times 0.7 \mathrm{~mm}$, polysporangiate, beak $0.2-0.4 \mathrm{~mm}$ long, connective prolonged $0.5 \mathrm{~mm}$, simply articulated with the filament, not appendaged. Ovary superior, obconic, 1.7 $1.8 \times 1.1-1.4 \mathrm{~mm}$, 3-locular, pale yellow-brown (dry state), glabrous; style 4.7 - $5 \mathrm{~mm}$ long, terete, yellow, stigma punctiform. Capsule ellipsoid, $2.1-2.4 \times 1.6-$ $1.7 \mathrm{~mm}$, dark, reddish-brown (dry state), dehiscing into 3 valves from apex, hypanthium persistent for a while, splitting and peeling away as capsule matures. Seeds not seen. Fig. 2.

RECOGNITION. Related to Microlicia morii Wurdack but differs in leaves sessile to subsessile, lacking veins, and blades $3-4.5 \times 0.6-0.9 \mathrm{~mm}$ (vs leaves with petioles c. $1 \mathrm{~mm}$ long, 1 - 3-nerved, and blades 4 $6.2 \times 1.6-2.8 \mathrm{~mm}$ in $M$. morii); sepals narrowly triangular, $1.8-2 \times 0.8-1 \mathrm{~mm}$ with apical seta (vs sepals triangular, $1.7 \times 1.7 \mathrm{~mm}$ without apical seta in $M$. morii).

DISTRIBUTION. Probably endemic to the vicinity of Catolés, Bahia, Brazil. Map 1.

SPECIMENS EXAMINED. BRAZIL. Bahia, Mun. Abaíra: Serra do Rei, 1700 - $1900 \mathrm{~m}, 13^{\circ} 18^{\prime} \mathrm{S}, 41^{\circ} 56^{\prime} \mathrm{W}, 3$ Feb. 1994, fl. fr., Ganev 2929 (holotype HUEFS!; isotypes K!, NY, US); Catolés, Serra do Barbado, 1750

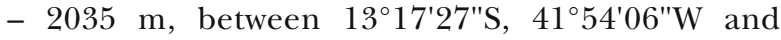
$13^{\circ} 17^{\prime} 50^{\prime \prime S}, 41^{\circ} 54^{\prime} 29^{\prime \prime} \mathrm{W}, 26$ Feb. 1994, fl. fr., Sano et al. in CFCR 14621 (K!, SPF!, US!).

HABITAT. Sandy, gravelly soil among rocks in campo rupestre between $1700-2035 \mathrm{~m}$.

CONSERVATION STATUS. Only two collections of Microlicia aureoglandulosa from two localities have so far been made. Serra do Barbado is a conservation area (Área de Proteção Ambiental da Serra do Barbado), with a low category of protection. The region suffers sporadic fires (man-made and natural) and being the highest mountain in $\mathrm{NE}$ Brazil, it is a popular tourist destination. As M. aureoglandulosa has a restricted extent of occurrence and area of occupancy $\left(8 \mathrm{~km}^{2}\right)$, it exists in less than five locations and its habitat is under threat from fire and tourist activity, it should be considered endangered EN Blab(iii)+2ab(iii) according to the IUCN categories and criteria (IUCN 2001, 2016).

ETYMOLOGY. The specific epithet refers to the golden glands that cover the stems, leaves, hypanthia and sepals. 


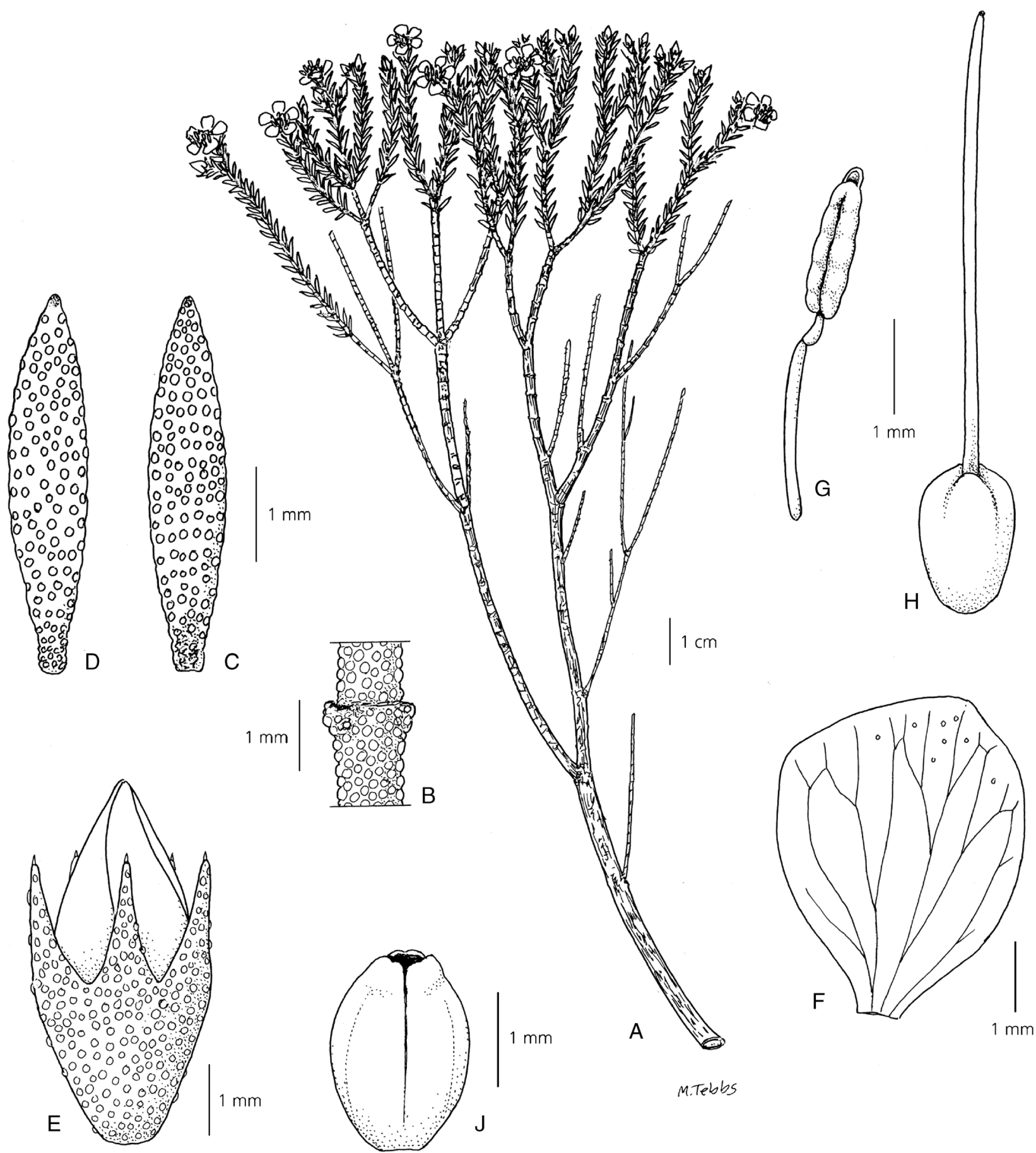

Fig. 2. Microlicia aureoglandulosa. A habit; B stem detail (showing indumentum of spherical glands); C leaf adaxial surface; D leaf abaxial surface; E flower bud; F petal; G stamen; H gynoecium; J capsule. A - D from Sano et al. 14621, E - J from Ganev 2929. DRAWN BY MARGARET TEBBS.

NOTES. Microlicia aureoglandulosa closely resembles M. morii, a species that occurs in Pico do Barbado, Mun. Abaíra and the Pico das Almas, Mun. Rio de Contas. They are both much-branched shrubs with yellow petals, isomorphic stamens with the connective simply articulate with the filament and not appendaged and polysporangiate anthers. Microlicia morii differs in having 1 - 3-nerved leaves with petioles c. $1 \mathrm{~mm}$ long, leaf blades $4-6.2 \times 1.6-2.8 \mathrm{~mm}$, petals $5.5-6 \times 4.5-4.7$ and sepals $1.7 \times 1.7 \mathrm{~mm}$ without an apical seta.

Microlicia catolensis Woodgyer \& Zappi, a species also endemic to the Catolés region, resembles M. aureoglandulosa in that it has leaves without 
discernible veins, yellow petals, isomorphic stamens with the connective simply articulate with the filament and not appendaged, and polysporangiate anthers. It differs in that it is a little-branched subshrub to $15 \mathrm{~cm}$ in height, is covered in a mixture of glandular trichomes and spherical, golden glands, has wider elliptic to ovate leaves $2-4 \times 1-1.5 \mathrm{~mm}$, ciliate leaf margins, leaf apices with a seta c. $1-1.5 \mathrm{~mm}$ long and larger petals $5.5-7 \times 5-6 \mathrm{~mm}$.

Microlicia aureoglandulosa also resembles M. isostemon Wurdack, a species endemic to the Pico das Almas in the Mun. Rio de Contas. They are both much-branched shrubs covered in spherical, golden glands, with leaves of a similar shape and size, isomorphic stamens with the connective simply articulate with the filament and not appendaged and polysporangiate anthers. $M$. isostemon differs in having 1-nerved leaves, petioles $0.5-0.7 \mathrm{~mm}$ long and pinkish-magenta petals.

If using the multi-access key to the species of Microlicia from Bahia (Woodgyer 2005), the formula for M. aureoglandulosa is: CDGJNQTVae.

In the checklist of the vascular plants of Catolés, both collections are cited by Zappi et al. (2003) as Microlicia sp. 14.

Microlicia crispa Woodgyer $\mathcal{E} R$. Romero sp. nov. Type: Brazil, Bahia, Mun. Abaíra, Jambreiro, 1100 - 1180 m, $13^{\circ} 17^{\prime} \mathrm{S}, 41^{\circ} 52^{\prime} \mathrm{W}, 31$ March 1994, fl. fr., Ganev 3007 (holotype HUEFS!, isotypes K!, NY, US).

http:/ /www.ipni.org/urn:lsid:ipni.org:names:77178070-1

Much branched shrub $0.6-1.30 \mathrm{~m}$ tall. Young stems quadrangular, light green to light brown (dry state), slightly winged, internodes c. $1-2 \mathrm{~mm}$ long, indumentum dense, a mixture of spherical, golden glands (some with a discernible stalk), pale greenishyellow, upwardly curled trichomes $0.2-0.3 \mathrm{~mm}$ long and straighter trichomes $0.5-0.8 \mathrm{~mm}$ long at nodes. Older branches leafless, leaf scars conspicuous giving stems a stepped appearance, becoming terete with age, bark greyish brown. Leaves inclined to ascending, light green, sessile or subsessile with petiole $0.3 \mathrm{~mm}$ long; blade elliptic to ovate, $2-3.5(-4) \times 0.8-1.8$ $\mathrm{mm}$, apex acuminate with a seta c. $0.3 \mathrm{~mm}$ long, margin entire, base cuneate; 1-nerved, more conspicuous on adaxial surface; impressed, golden glands with scattered, curled trichomes $0.3(-0.7 \mathrm{~mm})$ long often near margin on adaxial surface, spherical, golden glands and curled trichomes $0.1-0.3 \mathrm{~mm}$ long on abaxial surface. Flowers 5-merous, in clusters at tips of branches; sessile to subsessile. Hypanthium campanulate, $3.3-4 \times 2.5-3 \mathrm{~mm}$, green, with dense to moderate, spherical, golden glands (some with a discernible stalk) and flexuous trichomes $0.4-2 \mathrm{~mm}$ long, sometimes tinged pink; sepals linear to triangular, $1.5-2 \times 0.5-0.7 \mathrm{~mm}$, cream-pink, inner surface glabrous, outer surface indumentum as hypanthium, apex acuminate with seta $0.4-0.8 \mathrm{~mm}$ long, margin entire. Petals asymmetrically obovate, $6-7 \times 3.5-5.5$ $\mathrm{mm}$, magenta to purple to intense pink, apex apiculate with seta c. $0.2 \mathrm{~mm}$ long, spherical glands and often curled trichomes c. $0.1 \mathrm{~mm}$ long on upper half of outer surface. Stamens 10, dimorphic: large (antesepalous) stamens 5, filaments $2.5-3.5 \mathrm{~mm}$ long, dark pink, thecae $3-3.2$ (including beak) $\times 0.6-0.9$ $\mathrm{mm}$, yellow, polysporangiate, beak c. $0.3 \mathrm{~mm}$ long, connective prolonged $1.5-2 \mathrm{~mm}$, dark pink, ventral appendage $0.3-0.5 \mathrm{~mm}$ long; small (antepetalous) stamens 5, filaments $2-3 \mathrm{~mm}$ long, dark pink, thecae 2.8 (including beak) $\times 0.5-0.7 \mathrm{~mm}$, yellow, polysporangiate, beak c. $0.3 \mathrm{~mm}$ long, connective prolonged $0.7-1 \mathrm{~mm}$, dark pink, ventral appendage $0.2-0.3 \mathrm{~mm}$ long. Ovary superior, obovoid, $2 \times 1.3-$ $1.6 \mathrm{~mm}$, 3-locular, brown (dry state), glabrous; style 9 $10 \mathrm{~mm}$ long, terete, yellow or pink, stigma punctiform. Capsule ellipsoid, $3-3.6 \times 2.3-2.4 \mathrm{~mm}$, dark brown, dehiscing into 3 valves from apex, hypanthium persistent for a while, peeling away as capsule matures. Seeds $0.6 \times 0.3 \mathrm{~mm}$, pinkish-brown, testa pusticulate. Fig. 3 .

RECOGNITION. Related to Microlicia comparilis Wurdack but differs in leaves inclined to ascending and blades elliptic to ovate (vs leaves appressed, imbricate and blades lanceolate in M. comparilis); trichomes on stems and leaves curl upwards (vs trichomes on stems and leaves curl in varying directions in M. comparilis).

DISTRIBUTION. Abaíra and Rio de Contas region, Chapada Diamantina, Bahia, Brazil. Map 1.

SPECIMENS EXAMINED. BRAZIL. Bahia, Mun. Abaíra: Jambreiro, $1100-1180 \mathrm{~m}, 13^{\circ} 17^{\prime} \mathrm{S}, 41^{\circ} 52^{\prime} \mathrm{W}, 31$ March 1994, fl. fr., Ganev 3007 (holotype HUEFS!, isotypes $\mathrm{K}$ !, NY, US); Bicota, entre garimpo novo e Bicota, 1300 - $1420 \mathrm{~m}, 13^{\circ} 20^{\prime} \mathrm{S}, 41^{\circ} 51^{\prime} \mathrm{W}, 15$ Dec. 1993 , fl. fr., Ganev 2672 (HUEFS, K!, UEC!); Guarda Mor, arredores de Catolés, $1000-1100 \mathrm{~m}, 13^{\circ} 17^{\prime} \mathrm{S}, 41^{\circ} 51^{\prime} \mathrm{W}$, 22 March 1992, fl. fr., Stannard $\mathcal{E}$ Silva in H52785 (CEPEC, HUEFS, K!, SPF!); Morro do Cuscus, Água Limpa, 1400 m, $13^{\circ} 19^{\prime} \mathrm{S}, 41^{\circ} 52^{\prime} \mathrm{W}, 3$ March 1994, fl. fr., Ganev 2995 (HUEFS!, K!, NY, US); Rio de Contas, Kaiambola, Serra da Mesa, $1591 \mathrm{~m}, 13^{\circ} 23^{\prime} 51^{\prime \prime S}$, 41 52'43"W, 19 April 2002, fl. fr., Giulietti et al. 2273 (HUEFS!, K!).

HABITAT. Sandy, gravelly soil amongst rocks in campo rupestre between $1000-1591 \mathrm{~m}$.

CONSERVATION Status. Only five collections of Microlicia crispa have been made in the period between 1992 and 2002. The mountains of Abaíra and Rio de Contas regions are reasonably undisturbed, but habitats at lower elevations, which this species occupies, are under threat from burning for grazing and cultivation. As M. crispa has a restricted extent of occurrence and area of occupancy $\left(20 \mathrm{~km}^{2}\right)$, it exists 


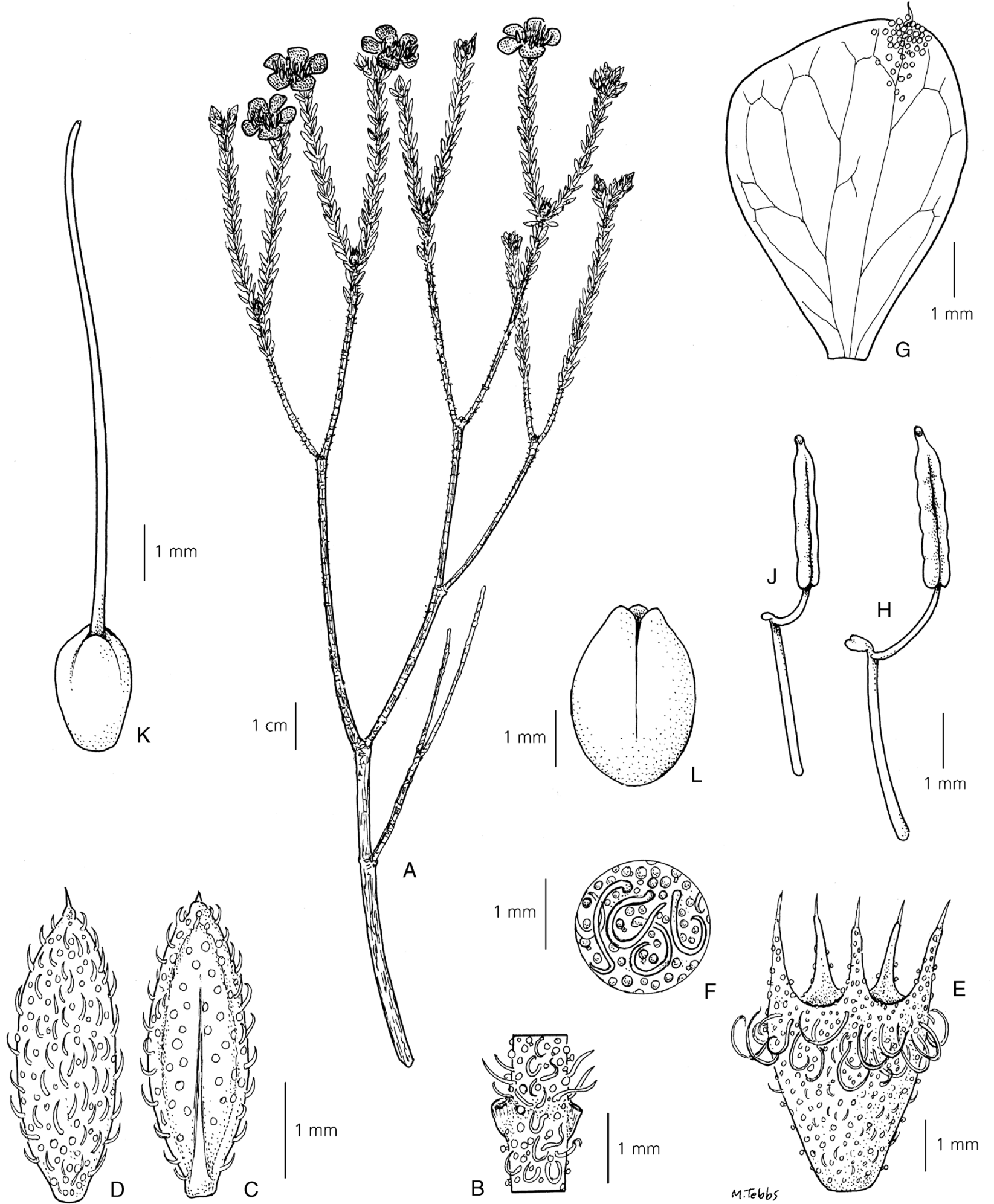

Fig. 3. Microlicia crispa. A habit; B stem detail (showing indumentum of spherical glands and upwardly curled trichomes); $\mathrm{C}$ leaf adaxial surface; D leaf abaxial surface; E hypanthium and sepals; $F$ hypanthium detail (showing indumentum of spherical glands and flexuous trichomes); G petal; H large (antesepalous) stamen; J small (antepetalous) stamen; K gynoecium; L capsule. From Ganev 3007. DRAWN BY MARGARET TEBBS. 
at no more than five locations and its habitat is under threat from fire and farming activity, it should be considered endangered EN Blab(iii)+2ab(iii) according to the IUCN categories and criteria (IUCN 2001, 2016).

ETYMOLOGY. The specific epithet relates to the curled trichomes found on the stems, leaves, hypanthia, sepals and petals.

NOTES. Microlicia crispa closely resembles M. comparilis, a species from the Chapada Diamantina region. They are both much-branched shrubs with magenta petals, similar sized sessile to subsessile, 1-nerved leaves and polysporangiate anthers. Microlicia comparilis differs in having trichomes on stems and leaves curled in varying directions, appressed, imbricate leaves, lanceolate leaf blades, sepals $0.9-1.1 \mathrm{~mm}$ wide, trichomes c. $0.2-0.3 \mathrm{~mm}$ long on hypanthia, glabrous petals and isomorphic stamens.

Microlicia crispa also resembles M. subaequalis Wurdack, a species from the Pico das Almas, Mun. Rio de Contas. They both have a similar, muchbranched habit with flowers in clusters at the apices of leafy branches, hypanthia with long trichomes, magenta petals, elliptic to ovate leaves of a similar size and polysporangiate anthers. Microlicia subaequalis differs in having imbricate to appressed, 1 - 3-nerved leaves with distinct petioles c. $0.5 \mathrm{~mm}$ long, leaf blades with straight trichomes c. $6 \mathrm{~mm}$ long, sepals $3 \times 2 \mathrm{~mm}$ and subisomorphic stamens.

If using the multi-access key to the species of Microlicia from Bahia (Woodgyer 2005), the formula for $M$. crispa is: BDGJNQUVaf.

In the checklist of the vascular plants of Catolés, Stannard E Silva in H52785 and Ganev 2995 \& 3007 are cited by Zappi et al. (2003) as Microlicia sp. 12 .

Microlicia curticalycina $R$. Romero $\mathcal{E}$ Woodgyer, sp. nov. Type: Brazil, Bahia, Rio de Contas, Serra dos Brejões, próximo ao Rio da Água Suja, divisa com distrito de Arapiranga, $13^{\circ} 49^{\prime} \mathrm{S}, 4^{\circ} 24^{\prime} \mathrm{W}, 1400$ m, 9 Aug. 1993, Ganev 2062 (holotype HUEFS!; isotypes K!, UEC!).

http://www.ipni.org/urn:lsid:ipni.org:names:77178078-1

Much branched subshrub, c. $0.5 \mathrm{~m}$ tall. Stem cylindrical, glabrous; young branches quadrangular densely covered in spherical, golden glands, glutinous; older branches becoming terete, glabrous and leafless with age, outer layer of bark peeling gradually to expose underlying brownish wood; internodes thickened, 1 $1.5 \mathrm{~mm}$ long. Leaves sessile, ascending, imbricate, concolorous; blade lanceolate, $3-4 \times 0.4-0.9 \mathrm{~mm}$, smooth, flattened or revolute, apex obtuse, base truncate, margin entire, midrib evident on abaxial surface, both surfaces covered with spherical, golden glands, glutinous. Flowers 5-merous, solitary, terminal and lateral, zygomorphic due to position of stamens and style; pedicel $0.3-0.6 \mathrm{~mm}$ long. Hypanthium oblong, $2-2.5 \times 1.3-1.6 \mathrm{~mm}$, brownish (in fresh and dried material), with spherical, golden glands; sepals triangular, $0.4-0.9 \times 0.7-0.9 \mathrm{~mm}$ (measured from the base), apex obtuse, indumentum as hypanthium. Petals oblong, $2.5-3 \times 1.7-2 \mathrm{~mm}$, yellow, glabrous, apex rounded. Stamens 10, yellow, isomorphic, filaments 1.6 - $2 \mathrm{~mm}$ long, thecae $1.6-2 \mathrm{~mm}$ long (including beak), polysporangiate, beak $0.1-0.2 \mathrm{~mm}$ long, connective prolonged $0.7-0.8 \mathrm{~mm}$, with ventral appendage rounded, $0.2-0.4 \mathrm{~mm}$ long. Ovary ovoid c. $1.5 \times 1 \mathrm{~mm}$, superior, 3-locular, glabrous; style $4.5-5.5 \mathrm{~mm}$ long, erect, terete, yellow, stigma punctiform. Capsule oblong, $2.5-3 \times$ $1.5-2 \mathrm{~mm}$, brown, dehiscing into 3 valves from the apex, covered by persistent hypanthium but which gradually peels away as fruit matures. Seeds $0.5-0.6 \times 0.2-0.3 \mathrm{~mm}$, numerous, slightly curved to one side, pale brown, testa areolate and foveolate. Fig. 4.

RECOGNITION. Related to Microlicia minima Markgr. but differs in having yellow petals (vs magenta petals in M. minima), sepals with obtuse apices (vs acute often aristate apices in M. minima), isomorphic stamens (vs dimorphic in $M$. minima) and ventral appendage rounded at the tip (vs bilobed in M. minima).

DISTRIBUTION. Microlicia curticalycina occurs in Rio de Contas, Bahia, Brazil, where it seems to be endemic. Map 1.

SPECIMENS EXAMINED. BRAZIL. Bahia, Rio de Contas, Serra dos Brejões, próximo ao Rio da Água Suja, divisa com distrito de Arapiranga, $13^{\circ} 49^{\prime} \mathrm{S}, 42^{\circ} 24 ' \mathrm{~W}, 1400 \mathrm{~m}$, 9 Aug. 1993, Ganev 2062 (holotype HUEFS!; isotypes $\mathrm{K}$ !, UEC!).

HABITAT. Campo rupestre with sandy soils at $1400 \mathrm{~m}$ elevation.

CONSERVATION STATUS. Microlicia curticalycina should be considered Critically Endangered (CR) B2ab(iii) due to the restricted extent of occurrence and area of occupancy $\left(\mathrm{AOO}=4 \mathrm{~km}^{2}\right.$ ), according to the IUCN categories and criteria (IUCN 2001, 2016). So far it is known only from a single collection. Due to its muchbranched habit, small leaves and yellow petals, characteristics very common in other Microlicia species occurring in Rio de Contas, we believe it may have been overlooked by collectors who mistakenly thought it had already been gathered.

ETYMOLOGY. The specific epithet refers to the very short sepals, $0.4-0.9 \mathrm{~mm}$ long, a feature uncommon in Microlicia species.

NOTES. Based on the multi-access key to the species of Microlicia from Bahia (Woodgyer 2005), the new species belongs to the group of species with small leaves up to a maximum of $8 \mathrm{~mm}$ long and up to $2 \mathrm{~mm}$ wide. Among these species, M. curticalycina bears some resemblance to $M$. minima, which occurs in Rio 


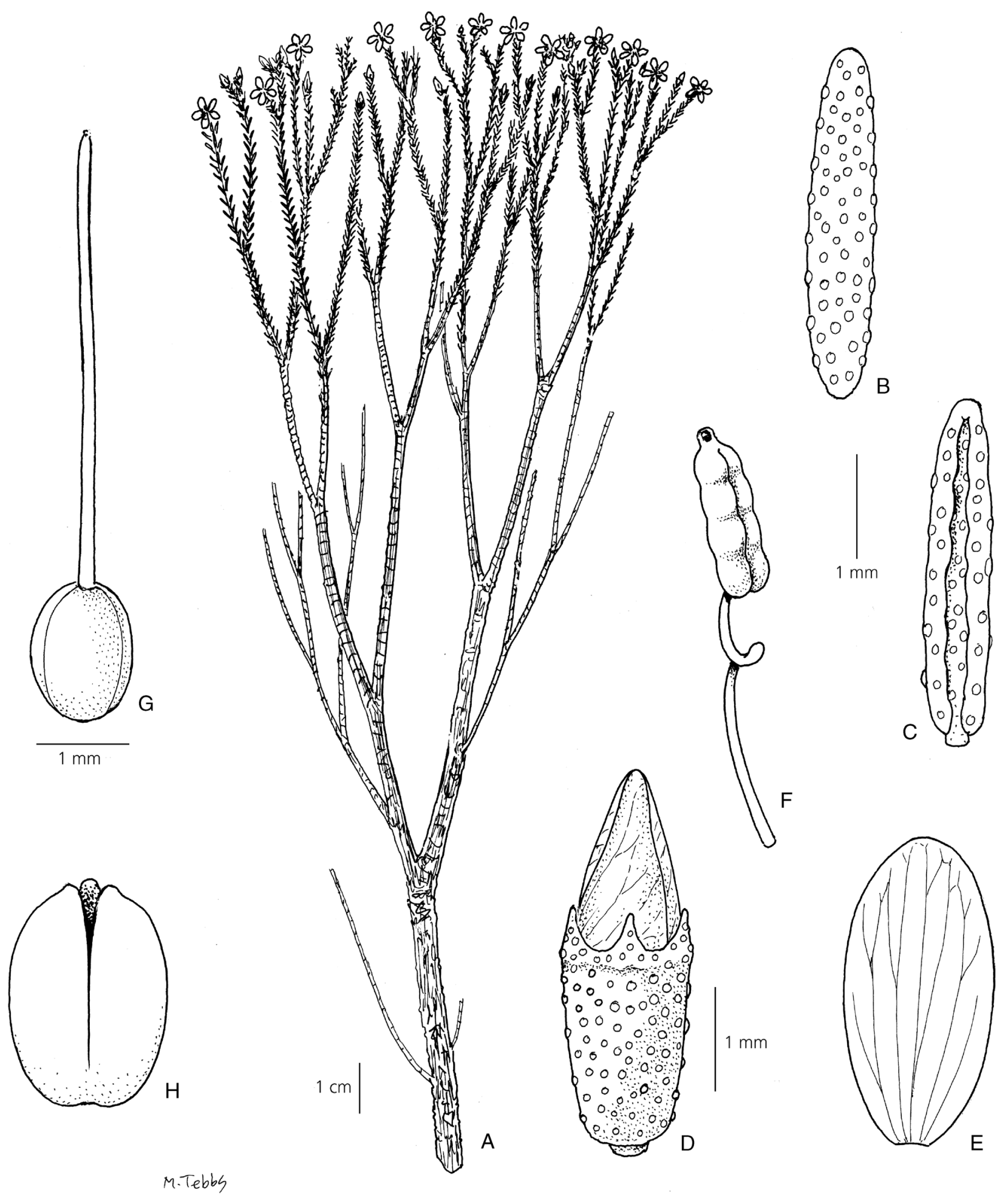

Fig. 4. Microlicia curticalycina. A habit; B leaf adaxial surface; C leaf abaxial surface; D flower bud; E petal; F stamen; G gynoecium; H mature capsule. From Ganev 2062. DRAWN BY MARGARET TEBBS.

de Contas, Mucugê and Abaíra. Both are branched subshrubs, covered in spherical, golden glands, sessile leaves, flowers with short pedicels $(0.3-0.6 \mathrm{~mm}$ long), oblong hypanthium, short, triangular sepals, anthers with beak $0.1-0.2 \mathrm{~mm}$ long and short prolonged connective. Microlicia minima differs in having magenta petals (vs yellow), sepals with acute apices, often aristate (vs obtuse), dimorphic stamens (vs 
isomorphic) and ventral appendage bilobed at the tip (vs rounded).

Microlicia curticalycina also resembles M. parvula, which occurs sympatrically in Rio de Contas, but also in Abaíra, Água Quente, Mucugê, Lençóis, Piatã and Seabra. It has yellow petals and stamens, indumentum of spherical, golden glands and isomorphic or subisomorphic stamens. In $M$. parvula the leaves are ovate or lanceolate, with rounded or cuneate bases and obtuse apices, flowers have campanulate hypanthia, polysporangiate anthers and connective prolonged $1.5-2 \mathrm{~mm}$.

If using the multi-access key to the species of Microlicia from Bahia (Woodgyer 2005), the formula for M. curticalycina is: CDGJNQTVae, the same formula for M. morii Wurdack, which occurs sympatrically in Rio de Contas. However, M. morii differs in having leaves $4-6.2 \times 1.6-2.8 \mathrm{~mm}$, petiole c. $1 \mathrm{~mm}$ long, petals c. $6 \times 4 \mathrm{~mm}$ and connective prolonged $0.4-0.5$ $\mathrm{mm}$, not appendaged (Wurdack 1995).

The new species is based on a single collection made 24 years ago in Rio de Contas. Despite the systematic treatment of Microlicia carried out by Woodgyer \& Nic Lughadha (1995) for the Flora of the Pico das Almas, this collection was not mentioned. In the checklist of the vascular plants of Catolés, this collection is cited by Zappi et al. (2003) as Microlicia sp. and in the inventory of Melastomataceae in Rio de Contas municipality carried out by Santos \& Silva (2005) as Microlicia sp. 3.

Microlicia ganevii Woodgyer $\mathcal{E} R$. Romero sp. nov. Type: Brazil, Bahia, Tanque do Boi, $1450 \mathrm{~m}, 13^{\circ} 16^{\prime} \mathrm{S}$, $41^{\circ} 54^{\prime} \mathrm{W}$, 6 July 1992, fl. fr., Ganev 614 (holotype HUEFS!; isotype $\mathrm{K}$ !).

http://www.ipni.org/urn:lsid:ipni.org:names:77178081-1

Slender, branched shrub $0.6-1.8 \mathrm{~m}$ tall. Young stems quadrangular, pale greenish-brown to pinkish-brown (dry state), sometimes blackened (due to fungal growth), slightly winged, internodes $3-8 \mathrm{~mm}$ long, indumentum dense, a mixture of spherical, golden glands, short-stalked, golden, gland-tipped trichomes $0.1-0.3 \mathrm{~mm}$ long and often scattered, golden trichomes $0.5-0.9 \mathrm{~mm}$ long. Older branches leafless, leaf scars often conspicuous giving a stepped appearance, becoming terete with age, bark grey, splitting to reveal pinkish stem beneath. Leaves ascending to appressed, imbricate, discolourous, abaxial surface mid-green to greenish-brown, adaxial surface midbrown to dark brown (dry state); petiole $1-1.5 \mathrm{~mm}$ long with dense, pale, short-stalked, gland-tipped trichomes c. $0.2 \mathrm{~mm}$ long; blade elliptic to obovate, $5-17 \times 2-9 \mathrm{~mm}$, apex acute with a thickened tip, margin entire, minutely ciliate, base cuneate; 3- nerved from base, (faintly 5-nerved on some wide leaves), more conspicuous on abaxial surface; indumentum on both surfaces dense, a mixture of impressed, spherical, golden glands and short-stalked, golden, gland-tipped trichomes $0.1-0.2 \mathrm{~mm}$ long. Flowers 5-merous, clustered at tips of branches, each in a leaf axil; sessile or pedicel c. $0.5 \mathrm{~mm}$ long. Hypanthium campanulate, $4-5 \times 3.5 \mathrm{~mm}$, pale green to yellowishgreen, pale brown (dry state), indumentum a mixture of spherical, golden glands and short-stalked, golden, gland-tipped trichomes $0.1-0.2 \mathrm{~mm}$ long; sepals narrowly triangular, $3.5-4 \times 0.7-1 \mathrm{~mm}$, pale brown to greenish-brown (dry state), sometimes with a darker, central mid-nerve, indumentum as hypanthium on both surfaces, apex narrowly acuminate, occasionally with a short seta, margin entire. Petals asymmetrically obovate, $8-11 \times 6-8 \mathrm{~mm}$, yellow sometimes with darker venation, glabrous, apex acute. Stamens 10 , subisomorphic, filaments 2.5 - $3.2 \mathrm{~mm}$ long, yellow, thecae 2.5 - 3.6 (including beak) $\times$ c. $1 \mathrm{~mm}$, golden yellow, polysporangiate, beak $0.3-0.4 \mathrm{~mm}$ long, connective prolonged $0.5-0.8 \mathrm{~mm}$, yellow, ventral appendage minute, c. $0.1 \mathrm{~mm}$ long, yellow. Ovary superior, obovoid, $2.5 \times 2.2 \mathrm{~mm}$, 3-locular, glabrous; style $8 \mathrm{~mm}$ long, terete, yellow, stigma punctiform. Capsule spheroid, $3-4.5 \times 2.5-3.3 \mathrm{~mm}$, golden brown (dry state), dehiscing into 3 valves from apex, hypanthium persistent, gradually peeling away as capsule matures. Seeds $0.7 \times 0.4 \mathrm{~mm}$, pinkish-brown, testa pusticulate. Fig. 5.

RECOGNITION. Related to Microlicia aurea Wurdack but differs in leaf blades 5-17 $\mathrm{mm}$ long and $3(-5)$ nerved (vs $6-10 \mathrm{~mm}$ long and 1 (-3) nerved in $M$. aurea); indumentum on stems a mixture of spherical glands and gland-tipped trichomes (vs stems glabrous in $M$. aurea); stamens subisomorphic (vs dimorphic in $M$. aurea).

DISTRIBUTION. Endemic to the vicinity of Catolés, Bahia, Brazil. Map 1.

SPECIMENS EXAMINED. BRAZIL. Bahia: Tanque do Boi, 1450 m, $13^{\circ} 16^{\prime} \mathrm{S}, 41^{\circ} 54^{\prime} \mathrm{W}, 6$ July 1992, fl. fr., Ganev 614 (holotype HUEFS!; isotype K!); Mun. Abaíra: Ladeira rochosa entre Ouro Fino e Pedra Grande, $1550 \mathrm{~m}$, $13^{\circ} 14^{\prime} \mathrm{S}, 41^{\circ} 54^{\prime} \mathrm{W}, 7$ Feb. 1992, fl. fr., Nic Lughadha $\mathcal{E}^{\circ}$ Queiroz in $\mathrm{H} 51057$ (CAS, CEPEC, HUEFS, K!, SPF); Abaixo da Serra do Rei, $1600 \mathrm{~m}, 13^{\circ} 18^{\prime} \mathrm{S}, 41^{\circ} 54^{\prime} \mathrm{W}, 18$ Aug. 1992, fl., Ganev 894 (HUEFS, K!).

HABITAT. Sandy or gravelly soil among rocks in campo rupestre, steep slopes between $1450-1600 \mathrm{~m}$.

CONSERVATION STATUS. Only three collections of Microlicia ganevii from three localities have so far been made. It has a similar distribution to M. aureoglandulosa but occurs at a lower altitude. This places it at more risk as local farmers burn the land as they believe it produces better grazing for cattle. If done occasionally this may not have 


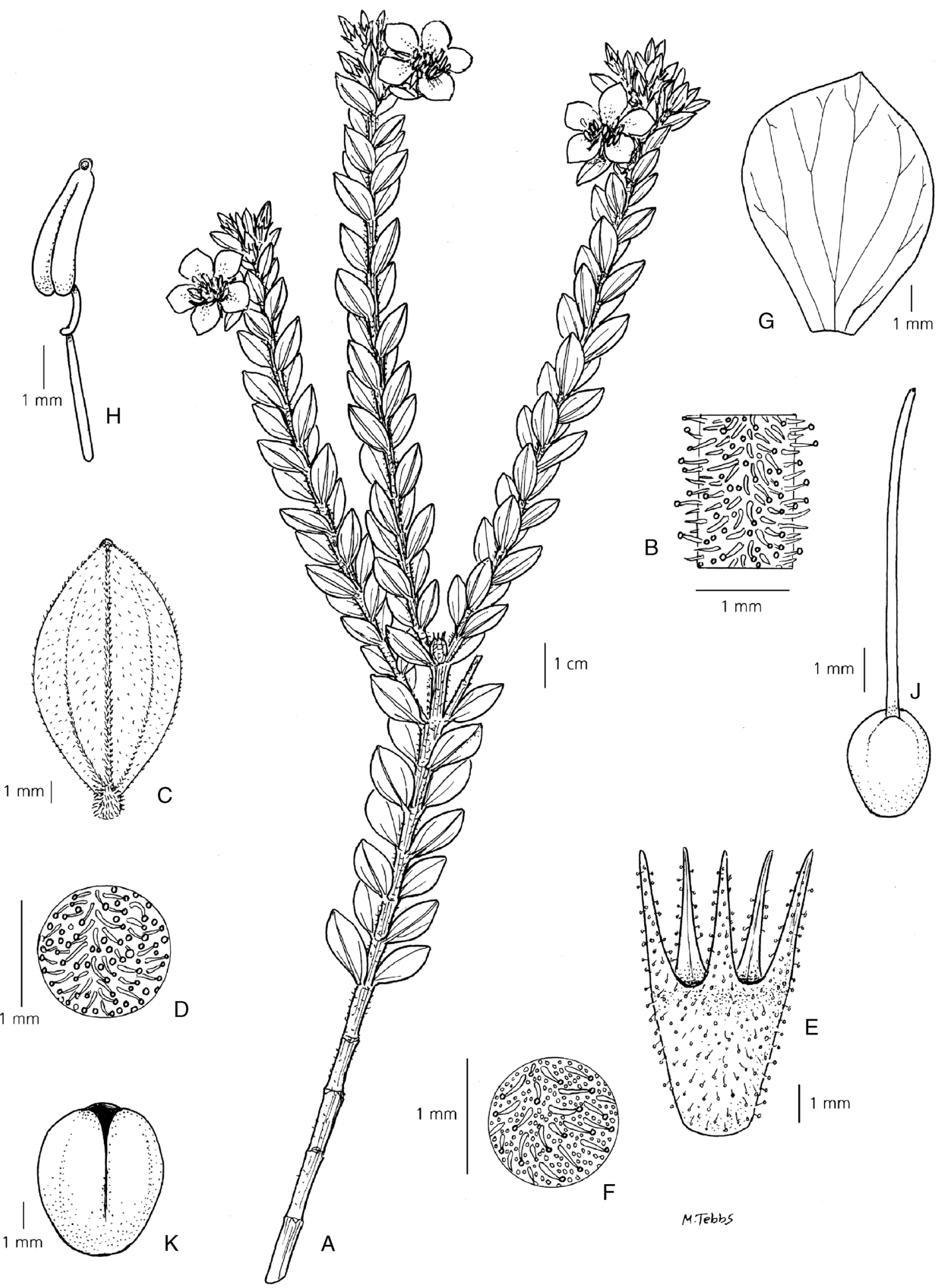

Fig. 5. Microlicia ganevii. A habit; B stem detail (showing indumentum of spherical glands and gland-tipped trichomes); $\mathrm{C}$ leaf abaxial surface; D leaf detail (showing indumentum of impressed, spherical glands and short-stalked, gland-tipped trichomes); $\mathrm{E}$ hypanthium and sepals; $\mathrm{F}$ hypanthium detail (showing indumentum of spherical glands and short-stalked, gland-tipped trichomes); G petal; H stamen; J gynoecium; K capsule. A - F, H - K from Ganev 614; G from Nic Lughadha \& Queiroz in H51057. DRAWN BY MARGARET TEBBS. 
too much impact, but if done frequently the flora can be considerably affected. As $M$. ganevii has a restricted extent of occurrence and area of occupancy $\left(12 \mathrm{~km}^{2}\right)$, it exists in less than five locations and its habitat is under threat from burning and cattle grazing, it should be considered endangered EN Blab(iii)+2ab(iii) according to the IUCN categories and criteria (IUCN 2001, 2016).

ETYMOLOGY. The species is named after Wilson Ganev, guide to the Catolés joint expedition between K, SPF and HUEFS (1991/1992), and plant collector in the Chapada Diamantina region of Bahia.

NOTES. Microlicia ganevii bears some similarity to M. aurea Wurdack, a Bahian species from the municipalities of Rio de Contas and Água Quente. Both are branched shrubs with yellow petals of a similar shape and size and with polysporangiate anthers. M. aurea differs in having glabrous stems, sessile to subsessile leaves, leaf blades impressed glandular punctate, 6 $10 \mathrm{~mm}$ long, 1 (-3) nerved and dimorphic stamens.

Microlicia ganevii also bears some similarity to M. chrysantha Wurdack, a branched shrub from the municipalities of Rio de Contas and Abaíra, Bahia which also has yellow petals and subisomorphic, polysporangiate stamens. $M$. chrysantha is otherwise quite different in that it has sessile leaves $13-32 \times 8-22 \mathrm{~mm}$, leaf blades ovate, bases cordulate and $5-7$ nerves. The sepals are $7.2-11.5 \times 2.2-3.5 \mathrm{~mm}$, petals $17-24 \times 12-18 \mathrm{~mm}$ and anthers $4.5-5.5 \mathrm{~mm}$ long with $3-4$ series of locules internally per theca (vs 2 series in $M$. ganevii) (Baumgratz et al. 1996).

Of the other 12 species of Microlicia with yellow petals which occur in Bahia, M. ganevii is readily distinguished from them by its leaf blades $5-17 \times 2-9 \mathrm{~mm}$ with a mixed indumentum of impressed, spherical, golden glands and short-stalked, golden glandtipped trichomes $0.1-0.2 \mathrm{~mm}$ long, $3(-5)$ nerves and petals $8-11 \mathrm{~mm}$ long.

If using the multi-access key to the species of Microlicia from Bahia (Woodgyer 2005), the formula for M. ganevii is: CEHKOQTVah or CEIKORTVah.

In the checklist of the vascular plants of Catolés, all three collections are cited by Zappi et al. (2003) as Microlicia sp.

Microlicia restingae $R$. Romero $\mathcal{E}$ Woodgyer sp. nov. Type: Brazil, Bahia: Belmonte, $24 \mathrm{~km}$ SW of Belmonte, on road to Itapebi, 24 March 1974, Harley et al. 17339 (holotype CEPEC!; isotypes CAS, IPA, K!, MO, NY!, RB, US!).

http://www.ipni.org/urn:lsid:ipni.org:names77178082-1

Subshrub 0.3 - $1 \mathrm{~m}$ tall. Stem cylindrical, outer layer of bark peeling gradually to expose underlying glabrous, brown- ish wood. Branches quadrangular, leafless with age, leaf scars evident, with spherical glands and pale trichomes $0.2-0.8 \mathrm{~mm}$ long, nodes thickened, with concentration of pale trichomes $0.4-1.7 \mathrm{~mm}$ long. Leaves horizontal to ascending, often discolorous, adaxial surface dark green, abaxial surface pale green (assessed when dry); petiole $0.3-0.6 \mathrm{~mm}$ long; leaf blade $4-10(-12) \times 1.5-2.5 \mathrm{~mm}$, lanceolate, apex acute, with an apical seta $0.5-0.8 \mathrm{~mm}$ long, base rounded or attenuate, margin entire or slightly crenulate, ciliate or not, adaxial surface with spherical glands or glabrous, abaxial surface with impressed spherical glands and pale trichomes 0.3 $0.9 \mathrm{~mm}$ long, sparse or not, or lacking, 3-nerved from the base, midrib conspicuously visible on both surfaces. Flowers solitary, terminal or lateral, zygomorphic due to position of stamens and style; pedicels $1-2 \mathrm{~mm}$ long. Hypanthium 2.5-3×1.5-2 mm, cylindrical, oblong, 10costate, with spherical, golden glands and sometimes pale trichomes; sepals 2 - $3 \mathrm{~mm}$ long, ascending, triangular, margin slightly crenulate, apex acute with a seta $0.7-1 \mathrm{~mm}$ long, indumentum as hypanthium, or with trichomes intercalated with sepals. Petals magenta, $7.5-9 \times 2.5-5 \mathrm{~mm}$, obovate, apex rounded, with a single glandular trichome $0.7-0.8 \mathrm{~mm}$ long. Stamens 10 , dimorphic, anthers polysporangiate, pore ventral: large (antesepalous) stamens 5, filaments $4-5 \mathrm{~mm}$ long, thecae $2-2.5 \mathrm{~mm}$ long (including beak), ovate-oblong, polysporangiate, beak c. $0.5 \mathrm{~mm}$ long, connective prolonged $5-5.5 \mathrm{~mm}$, ventral appendage $(0.8-) 1.3-$ $1.5 \mathrm{~mm}$ long, truncate at the tip; small (antepetalous) stamens 5 , filaments $4-4.5 \mathrm{~mm}$ long, thecae c. $1.5 \mathrm{~mm}$ long, ovate, beak $0.3-0.5 \mathrm{~mm}$ long, connective prolonged $1.5-1.8 \mathrm{~mm}$, not appendaged. Ovary superior, 3-locular, glabrous; style c. $8 \mathrm{~mm}$ long, slightly curved, stigma punctiform. Capsule $3-4 \times 2-2.5 \mathrm{~mm}$, globose, with ovary apex exposed, dehiscing into 3 valves from the apex, covered by persistent hypanthium which gradually peels away as fruit matures. Seeds c. $0.5 \times 0.2-$ $0.3 \mathrm{~mm}$, numerous, slightly curved to one side, testa foveolate. Fig. 6.

RECOGNITION. Related to Microlicia subsetosa DC. but differs in having leaves $4-12 \times 1.5-2.5 \mathrm{~mm}$ (vs $2.3-$ $3.5 \times 1-1.5 \mathrm{~mm}$ in $M$. subsetosa), sparse to dense indumentum of pale trichomes $0.2-0.8 \mathrm{~mm}$ long (vs $0.3-0.4 \mathrm{~mm}$ long in M. subsetosa).

DISTRIBUTION. Endemic to Bahia, Brazil, occurring in the southeastern region of the state. Map 1.

SPECIMENS EXAMINED. BRAZIL. Bahia, Belmonte: $24 \mathrm{~km}$ SW of Belmonte, on road to Itapebi, 24 March 1974, Harley et al. 17339 (holotype CEPEC!; isotypes CAS, IPA, K!, MO, NY!, RB, US!); c. 30 km SW de Belmonte, 8 Jan. 1981, Carvalho $\mathcal{E}^{\circ}$ Gatti 478 (CEPEC, US!); Canavieiras: restinga, 28 June 1966, Belém Eे Pinheiro 2430 (NY, UB); $21 \mathrm{~km}$ na rodovia Canavieiras-Una, BA 001, Fazenda Campo Lúcio, 4 June 1981, Hage E् Santos 907 (HUEFS); rodovia 


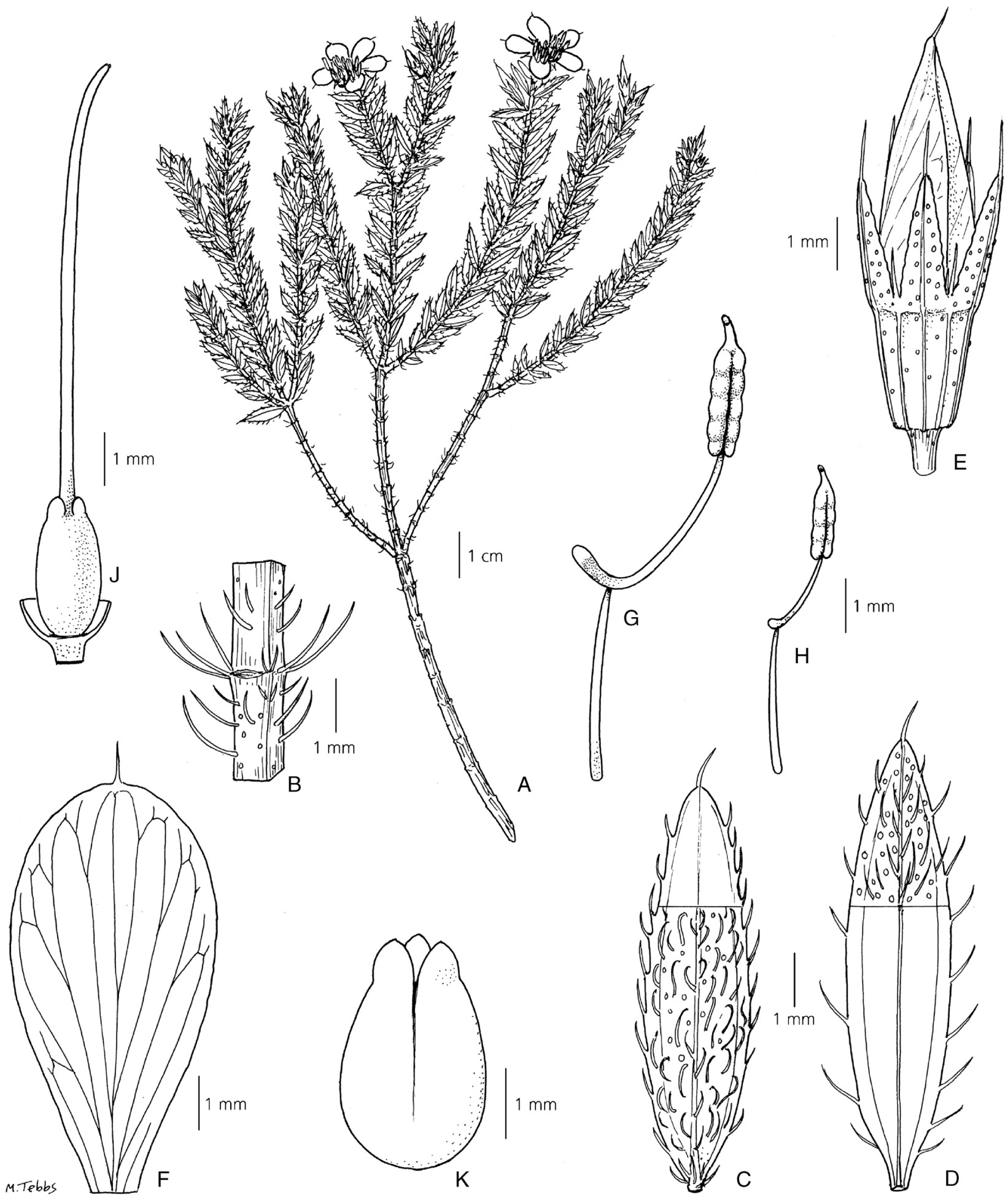

Fig. 6. Microlicia restingae. A habit; $\mathrm{B}$ stem detail (showing indumentum of spherical glands and pale trichomes); $\mathrm{C}$ leaf abaxial surface; D leaf adaxial surface; E flower bud; F petal; G large (antesepalous) stamen; H small (antepetalous) stamen; J gynoecium; K mature capsule. A, B, D - K from Harley et al. 17339; C from Harley et al. 18075. DRAWN BY MARGARET TEBBS.

Canavieiras-Santa Lúzia, km 19, 15 June 1988, Silva et al. 2436 (MBM, SP, SPF); rodovia Canavieiras-
Santa Luzia, 21 Jan. 1998, Amorim et al. 2115 (CEPEC, NY, SP). Prado, $16 \mathrm{~km} \mathrm{~S}$ of Cumuruxatiba 
on the road to Prado, 18 Jan. 1977, Harley et al. 18075 (K!, NY, US!).

HABITAT. Microlicia restingae occurs in open areas of restingas (coastal vegetation) on sandy and wet soil between $5-8$ m elevation.

CONSERVATION STATUS. The first collection of Microlicia restingae was made in 1966 and the last in 1998 in the restingas of south Bahia, a type of vegetation that has suffered strong human pressure over the years from development along the coast to support tourism, and is therefore very much under threat. Due to the restricted extent of occurrence and area of occupancy $(\mathrm{AOO}=28$ $\mathrm{km}^{2}$ ), M. restingae should be considered endangered (EN) Blab(iii)+2ab(iii) according to the IUCN categories and criteria (IUCN 2001, 2016).

ETYMOLOGY. The specific epithet refers to the restricted occurrence of the new species to the Brazilian coastal vegetation known as restinga.

NOTES. Wurdack (1983) in describing Microlicia subaequalis, endemic to Bahia, commented that a series of collections from eastern Bahia (Belém et al. 757, 1675, 2430; Harley et al. 17339, 18075; Vinha 135; Hage Eं Santos 907; Santos et al. 3349; Carvalho E̋ Gatti 478) previously determined by him as Microlicia aff. subsetosa DC. should be considered a pubescent variant of $M$. setosa (Spreng.) DC. When examining the type collection of $M$. setosa and recent collections made in Minas Gerais (G. Hatschbach et al. 54251, 68025, 68033; G. Hatschbach $\mathcal{E}$ O. S. Ribas 55042, all seen in HUFU; G. Hatschbach E O. S. Ribas 52003 in MBM, US; H. S. Irwin et al. 27220 in NY) we verified that five specimens from Bahia determined by Wurdack as M. setosa were very distinct and we recognise them as $M$. restingae.

Microlicia restingae resembles $M$. setosa, which is endemic in campos rupestres from Goiás and Minas Gerais (Romero \& Woodgyer 2016). Both have lanceolate leaves, acute apices with an apical seta 0.4 $1.2 \mathrm{~mm}$ long, cylindrical and oblong hypanthium, often slightly 10-costate, triangular sepals with acute apices and an apical seta $0.5-2.5 \mathrm{~mm}$ long. In M. setosa however, the leaves are sessile, rarely with a short petiole up to $0.2 \mathrm{~mm}$ long and the whole plant is covered in spherical glands.

Microlicia restingae has a variable indumentum covering the reproductive and vegetative structures. The branches have spherical, golden glands and pale trichomes $0.2-0.8 \mathrm{~mm}$ long ranging from sparse to dense. The hypanthium can have an indumentum of spherical glands and a single, pale trichome between the sepals, spherical glands and pale trichomes sparsely or densely covering the hypanthium and sepals or rarely with spherical glands only (A. M. Amorim et al. 2115).

Microlicia subsetosa occurs in Rio de Contas, Barra da Estiva and Serra de Açurua, in Bahia, and like M. restingae has a short petiole $0.2-0.3 \mathrm{~mm}$ long, indumentum of glands and pale trichomes, magenta petals and dimorphic stamens with bicolorous anthers. M. subsetosa however is a small subshrub $0.2-0.3 \mathrm{~m}$ tall, with small leaves $2.3-3.5 \times 1-1.5 \mathrm{~mm}$ and a dense indumentum of pale trichomes $0.3-0.4 \mathrm{~mm}$ long covering the whole plant.

If using the multi-access key to the species of Microlicia from Bahia (Woodgyer 2005), the formula for $M$. restinga is: BDHJOQUVbg.

\section{Acknowledgements}

The authors are grateful to the curators of HUEFS and SPF for sending specimens to Kew, to Margaret Tebbs for preparing the illustrations, to Luciano Pataro for preparing the map, and to Ray Harley, Nicholas Hind and Daniela Zappi for their advice. Rosana Romero thanks CNPq (Reflora 563541/2010_ 5) for financial support; Capes for post-doctoral fellowship (Reflora and Ciência Sem Fronteiras proc. 9612/12-2); Eve Lucas and Eimear Nic Lughadha for their kindness and support during her stay at the Royal Botanic Gardens, Kew.

Open Access This article is distributed under the terms of the Creative Commons Attribution 4.0 International License (http://creativecommons.org/ licenses/by/4.0/), which permits unrestricted use, distribution, and reproduction in any medium, provided you give appropriate credit to the original author(s) and the source, provide a link to the Creative Commons license, and indicate if changes were made.

\section{References}

Aguiar, L. G. P. A. (2012). A tribo Microlicieae (Melastomataceae) no município de Mucugê (Chapada Diamantina), Bahia, Brasil. Dissertação de Mestrado. (unpubl.). Universidade Federal de Feira de Santana.

Almeda, F. \& Martins, A. B. (2001). New combinations and new names in some Brazilian Microlicieae (Melastomataceae), with notes on the delimitation of Lavoisiera, Microlicia and Trembleya. Novon 11: $1-7$.

\& _-_- (2012). Microlicia wurdackiana

(Melastomataceae: Microlicieae); a new species from Bahia, Brazil. Kew Bull. 67: 467 - 470.

Bachman, S., Moat, J., Hill, A. W., de la Torre, J. \& Scott, B. (2011). Supporting Red List threat assessments with GeoCAT: geospatial conservation assessment tool. In: V. Smith \& L. Penev (eds), eInfrastructures for data publishing in biodiversity science. ZooKeys 150: 117 - 126. (Version BETA).

Baumgratz, J. F. A., Souza, M. L. D. R., Woodgyer, E. M. \& Nic Lughadha, E. M. (1996). Polysporangiate 
anthers: described for the first time in Melastomataceae. Kew Bull. 51: 133 - 144.

Brade, A. C. (1962). Algumas espécies novas do gênero Microlicia (Melastomataceae) da Flora do Brasil. Arq. Bot. São Paulo. 3: 249 - 261.

Candolle, A. P. de (1828). Prodromus systematis naturalis regni vegetabilis 3 . Treuttel \& Würtz, Paris.

Chamisso, A. (1834). De plantis in expeditione speculatoria Romanzoffiana et in herbariis regiis berolinensibus observatis. Melastomaceae americanae. Linnaea 9: 368 - 460.

Cogniaux, A. (1883). Microlicia. In: C. F. P. Martius†, A. G. Eichler \& M. Urban, Flora Brasiliensis 14: 38 121, 591 - 594. Frid. Fleischer, Monachii, Lipsiae.

(1891). Melastomaceae. In: A. Candolle \& C. Candolle (eds), Monographiae Phanerogamarum 7: 1 1256. G. Masson, Paris.

Don, D. (1823). An illustration of the natural family of plants called Melastomataceae. Mem. Wern. Nat. Hist. Soc. 4: 276 - 329.

Hoehne, F. (1922) Melastomataceae. Anexos das Memórias do Instituto de Butantan. Companhia Melhoramentos de São Paulo, São Paulo.

IUCN (2001). IUCN Red List Categories and Criteria: Version 3.1. Prepared by the IUCN Species Survival Commission. IUCN, Gland and Cambridge.

(2016). The IUCN Red List of Threatened Species, version 2016-1. <http://www.iucnredlist.org>. Accessed 31 August 2016.

Markgraf, F. (1927). Melastomataceae. In: R. Pilger (ed.), Plantae Luetzelburgianae Brasilienses VII. Notizbl. Bot. Gart. Berlin-Dahlem 10: 43 - 54.

Naudin, C. (1845). Additions a la flore du Brésil méridional. Ann. Sci. Nat., Bot., sér. 3, 3: $171-189$.

(1849). Melastomacearum quae in Museo parisiensicontinentur. Monographicae descriptionis. Ann. Sci. Nat., Bot., sér. 3, 12: 196 - 284.

Pataro, L., Romero, R. \& Roque, N. (2013). Four new species of Microlicia (Melastomataceae) from Chapada Diamantina, Bahia, Brazil. Kew Bull. 68: 285 - 293.

Romero, R. (2013a). Taxonomic notes in Microlicia (Melastomataceae, Microlicieae). Phytotaxa 110: 48- 54. (2013b). Lectotypifications and synonyms in Microlicia (Melastomataceae, Microlicieae). Kew Bull. 68: $635-639$.

\& Martins, A. B. (2002). Melastomataceae do Parque Nacional da Serra da Canastra, Minas Gerais, Brasil. Revista Bras. Bot. 25: 19 - 24.

\& Woodgyer, E. M. (2014). Rediscovery of two species of Microlicia (Melastomataceae) in Minas Gerais, Brazil. Phytotaxa 173: 41 - 48.

\& Woodgyer, E. M. (2016). Microlicia. In: Lista de Espécies da Flora do Brasil, Jardim Botânico do Rio de
Janeiro. Available from <http:// floradobrasil.jbrj.gov.br/jabot/floradobrasil/ FB9782>. Accessed 31 August 2016.

, Silva, K. \& Simão, D. (2015a). Two new species of Microlicia (Melastomataceae) from Minas Gerais, Brazil: morphology and leaf anatomy. Nord. J. Bot. 33 (2): $178-185$.

\& __ (2015b). Microlicia cogniauxiana and Microlicia naudiniana (Melastomataceae), Two new species from the Espinhaço Range, Brazil. Syst. Bot. 40 (4): 1012 - 1021.

Santos, A. K. A \& Silva, T. R. S. (2005). A família Melastomataceae no município de Rio de Contas, Bahia, Brasil. Sitientibus Sér. Ci. Biol. 5: $76-92$.

Thiers, B. [continuously updated]. Index Herbariorum: A global directory of public herbaria and associated staff. New York Botanical Garden's Virtual Herbarium. <http://sweetgum.nybg.org/science/ih/>. Accessed 31 August 2016.

Ule, E. (1908). Melastomataceae. Bot. Jahrb. Syst. 42: $232-236$.

Woodgyer, E. M. (2005). Multi-access key and checklist to the species of Microlicia (Melastomataceae) in Bahia, Brazil. Kew Bull. 60: 441 - 448. \& Nic Lughadha, E. (1995). Microlicia, pp. 466 478. In: B. L. Stannard (ed.), Flora of the Pico das Almas: Chapada Diamantina, Bahia, Brazil. Royal Botanic Gardens, Kew.

\& Zappi, D. C. (2005). Two new species of Microlicia D. Don (Melastomataceae) from Catolés, Bahia, NE Brazil. Kew Bull. 60: 435 - 440. \& _ (2009). Two new species of Microlicia D. Don (Melastomataceae) from Bahia, NE Brazil. Kew Bull. 64: 279 - 284.

Wurdack, J. J. (1974). Certamen Melastomataceis XXIII. Phytologia 29 (2): 135 - 151.

(1981). Certamen Melastomataceis XXXIII. Phytologia 49: 148 - 158.

(1982). Certamen Melastomataceis XXXIV. Phytologia 50: 297 - 308.

(1983). Certamen Melastomataceis XXXVI. Phytologia 53: 121 - 137.

(1988). Certamen Melastomataceis XXXVIII. Phytologia 64: 293 - 301.

(1995). New species of Melastomataceae from Bahia, Brazil. Kew Bull. 50: 821 - 825.

Zappi, D. C., Lucas, E., Stannard, B. L., Nic Lughadha, E., Pirani, J. R., Queiroz, L. P., Atkins, S., Hind, D. J. N., Giulietti, A. M., Harley, R. M. \& Carvalho, A. M. (2003). Lista das plantas vasculares de Catolés, Chapada Diamantina, Bahia, Brasil. Bol. Bot. Univ. São Paulo 21: 345 - 398. 